\title{
Relative pronouns as sluicing remnants
}

Anikó Lipták

*pre-publication version, final version under copyright*

\begin{abstract}
This paper demonstrates on the basis of novel data from Hungarian that contrary to received opinion, sluicing is possible inside relative clauses. It shows that sluicing can affect a relative clause to the exclusion of its relative pronoun in headless or headed relatives that can be considered non-canonical free choice expressions. In sluicing, the relative pronoun that gets stranded in the ellipsis process furthermore bears the major stress associated with the relative clause, a cross-linguistically rare possibility in languages. The findings throw a new light on theories concerned with the syntactic licensing of sluicing and ellipsis in general, pointing at the crucial role of prosody.
\end{abstract}

Keywords: sluicing, ellipsis, relative clauses, TP-deletion, antecedent-contained deletion

\section{Introduction: restrictions on sluicing}

Sluicing, first identified and named in Ross (1969), is an instance of clausal ellipsis that leaves a single wh-remnant and deletes a TP in contexts in which the content of the TP is given in the preceding discourse. According to the generally adopted view in the syntactic literature sluicing is restricted to $w h$-interrogative clauses (cf. 1), and is not allowed in wh-relative clauses (cf. 2) (ellipsis is indicated by strikethrough, data from Lobeck 1995: p. 57, ex. 57a; Merchant 2001: p. 59, ex. 67 respectively, see also van Riemsijk 1987):

(1) Someone stole the car, but they don't know who stole the car.

(2) a. * Someone wants to talk to Mary, but the person who wants to talk to Mary is too shy to approach her.

b. * Someone stole the car, but they couldn't find the person who stole the car.

The above difference between interrogative and relative environments when it comes to the syntactic licensing of sluicing has puzzled syntacticians for a while now, but has received no explanation in the literature so far — researchers merely state that interrogativity is a quintessential licensing requirement on sluicing for reasons unknown. In Lobeck's governmentbased framework of ellipsis licensing, interrogative complementizers are said to possess a [+wh]feature that makes them a 'strong' ellipsis licensor, contrary to relative complementizers with a [-wh] feature, which is incapable of licensing. In Merchant's implementation, where ellipsis is licensed by a syntactic feature [E] on the $\mathrm{C}^{\circ}$-head of constituent questions, the sluicing-type [E] feature possesses uninterpretable $\left[\mathrm{uwh}^{*}, \mathrm{uQ}^{*}\right]$-features that require overt checking against an interrogative complementizer but do not allow checking against any other complementizer type, 
e.g. a relative complementizer. ${ }^{1}$ Accordingly, the proper configuration for ellipsis licensing is as in (3).

(3)

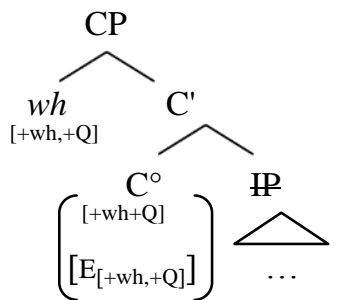

In this paper, it will be argued that the puzzle concerning the interrogative vs. relative distinction in ellipsis licensing does not in fact exist: relative clauses can also have their TP elided to the exclusion of their relative pronoun, similarly to what one finds in interrogatives. The novel data upon which this claim will be based come from Hungarian. In this language sluicing inside relatives — 'relative sluicing' as it will be referred to below — is a productive pattern and shows the traits of clausal ellipsis. It will be shown that relative sluicing furthermore shows a specific prosodic profile that is cross-linguistically rare, and that the availability of this profile might constain the availability of relative sluicing across languages.

The structure of the paper is as follows. Section 2 presents the novel data of relative sluicing from the National Hungarian Corpus and describes the environments in which relative sluicing can be found. Section 3 spells out several arguments for taking these data to involve instances of clausal ellipsis. Section 4 details the syntactic and prosodic licensing of relative sluicing and sheds light on its cross-linguistically rare distribution. Section 5 summarizes.

\section{Relative sluicing: novel data from Hungarian}

Hungarian relative clauses are structurally similar to interrogative clauses in that they contain movement of a $w h$-type pronoun to the left periphery. Relative pronouns are built on the $w h$-word paradigm, and are prefixed by $a$-, a morpheme originating from a demonstrative (to be glossed as REL in what follows).

As a search in the Hungarian National Corpus (HNC, http://corpus.nytud.hu/mnsz/) reveals, relative clauses need not be fully pronounced in Hungarian. Next to examples in which relatives contain VP ellipsis or ellipsis of a postfocal constituent (see van Craenenbroeck and Lipták 2006 for examples of this sort), the corpus contains many examples in which the sole overt item in a relative clause is the relative pronoun itself, and the missing predicate in the relative clause is identical to the embedding predicate in the matrix clause. This is a pattern of relative clause formation that is perfectly productive and can be found both in literary style and in oral language use. $^{2}$ (4) and (5) illustrate.

\footnotetext{
${ }^{1}$ The syntactic $[\mathrm{E}]$ feature hosts all the syntactic, semantic and phonological properties which distinguish elliptical constructions from non-elliptical ones. For sluicing, $[\mathrm{E}]$ contains the following properties:

(i) a. $\quad$ the syntax of [E]: $\quad \mathrm{E}_{\left[u \mathrm{wh}^{*}, u \mathrm{Q}^{*}\right]}$

b. the phonology of $[\mathrm{E}]: \varphi_{\mathrm{TP}} \rightarrow \varnothing / \mathrm{E}$

c. $\quad$ the semantics of $[\mathrm{E}]: \quad \llbracket \mathrm{E} \rrbracket=\lambda \mathrm{p}: \mathrm{e}-\operatorname{GIVEN}(\mathrm{p})[\mathrm{p}]$

${ }^{2}$ All examples in this section and sections 3.1. and 3.2, unless otherwise indicated, are from the Hungarian National Corpus. Abbreviations in the glossing are as follows: $\mathrm{ACC}=$ accusative; $\mathrm{DAT}=$ dative; $\mathrm{RC} / \mathrm{CP}_{\text {rel }}=$ relative clause, $\mathrm{REL}$

$=$ relative morpheme. Relative clauses are indicated/bracketed here according to the head-external analysis in which
} 
(4) A rovaroknak mindig 3 pár lábuk van, a százlábúaknak meg

the insects-DAT always 3 pair foot-POSS-3PL is the millipedes-DAT PRT

annyi, [RC amennyi $\operatorname{ran}$ nekik ].

that-many REL-how.many is they-DAT

'Insects always have 3 pairs of feet. Millipedes on the other hand have as many as they do.'

(5) Ismerőssel eggyel találkozott, mulatságosnak találta, hogy éppen

acquiantance-WITH one-WITH met-3SG funny-DAT found-3sG that just

azzal, [RC akivel találkozott ].

that-WITH REL-who-WITH met-3SG

'Acquiantances, he met only one, and he found it funny that he met whoever he did.'

As the careful reader has noticed the relative clauses in (4) and (5) are headed by a pronominal constituent, representing the so-called pronominally headed relative pattern (cf. Kenesei 1992, aka light-headed relatives in Citko 2004). Headless or free relatives can also host relative sluicing: they are most naturally preceded by the discourse particle már 'at least' (cf. 6,7) or introduce a comparative clause (cf. 8).

(6) Az építményadót eddig ugyanis a kerületek szedték — már the property.tax-ACC till.now PRT the districts collected-3PL PRT ahol szedték.

REL-where collected

'It was the districts that collected the property tax — at least in places wherever they did.'

(7) Micsoda sportesemény volt! Csupa élmény és élvezet! Már akinek what sportevent was pure experience and enjoyment PRT REL-who-DAT esupa élmény és élvezet volt.

pure experience and enjoyment was

'What a sports event it was! A great experience and joy. At least for whoever it was great experience and joy.'

[...] nem tudom, hogyan alakult volna a sorsom, not know-1SG how developed-3SG COND the life-POSs-1SG

de bizonyos, hogy másképp, mint ahogy alakult. but sure that differently than REL-how developed-3SG '[...] I don't know how my life would have turned out to be, but surely different from the way it did.'

The sluiced relative pronoun can also be contrastive with respect to another relative pronoun in the preceding discourse (cf. 9).

(9) Olvasni kell. Elképesztő, AMIT ír, elképesztő, AHOGY ír. read-INF must astonishing REL-what-ACC write-3SG astonishing REL-how write-3SG 'You have to read him. It's astonishing what he writes, and also astonishing how he does.'

the head is generated external to the relative clause, but this choice is immaterial for the present purposes. Note also that in examples (4)-(9), the elliptical material is indicated by strikethrough to familiarize the reader with the content of the relative clause. In the rest of the examples, the elided material is not spelled out for reasons of space. 
In all the above cases, ellipsis is truly optional: the elliptical parts (indicated by strikethrough) can also be fully pronounced, with exactly the same meaning. Note further that the elliptical TP in these relative clauses is structurally identical to the antecedent TP in the sense that it does not contain a cleft underlyer: as none of the examples contain a nominative relative pronoun, they cannot serve as a cleft pivot.

That relative sluicing is always hosted by headless and pronominally headed relatives in Hungarian is not an accident: what unites these relative clauses is that they have a definite or universal (and necessarily restrictive) interpretation. While all examples so far are definite in reading, the following example (source: Élet és irodalom 19 April 2013) illustrates a universal one.

(10) Egy olyan országban élünk, ahol szinte "minden" és "mindenki" következmények an such country-IN live-3PL where almost everthing and everyone consequences [...] nélkül teheti mindazt, amit... without do-POT-3SG all-that REL.what-ACC

'We live in a country where everything and everyone can do whatever it/he does, without consequences.'

Unlike definite/universal relatives, indefinite relatives or relatives with a non-restrictive interpretation cannot host sluicing in Hungarian, consider the ungrammaticality of the following two examples, both modified variants of (5) above.
* Ismerössel
eggyel
találkozott, $[\ldots]$
egy osztálytársával, akivel. acquiantance-WITH one-WITH met-3SG an classmate
'Acquiantances, he met one, ... an old classmate, who he met.'
Ismerössel
eggyel
találkozott, [...] Péterrel, Péter-WITH
akivel.
acquiantance-WITH one-WITH met-3SG
'Acquiantances, he met one, ... Péter, who he met.'
REL-who-WITH

The obligatory definite/universal semantics of relative sluicing makes these relative clauses functionally equivalent to headless relatives in English, which are also known to have either a definite or a universal reading (cf. Jacobson 1995, Dayal 1997, Caponigro 2003).

(13) I ordered what(ever) John did.

i. 'I ordered the thing John ordered.' definite reading

ii. 'I ordered everything John ordered.' universal reading

This functional equivalence extends to the pragmatic import of the relative clauses as well: in all cases but the contrastive relative in (9), sluiced relatives are used to signal irrelevance, vagueness or ignorance on the side of the speaker - characteristics of the use of English headless relatives as well (see Jacobson 1995, Dayal 1997, von Fintel 2000 among others). Accordingly, when using sluiced relatives, Hungarian speakers indicate that they deem the relative's exact reference irrelevant to the conversational purposes or that they do not choose or are able to reveal it. In this sense, sluiced relatives can be considered elliptical variants of non-canonical free choice relatives in the language and can be paraphrased best with an -ever type free relative in English (see the translations of the examples above). 


\section{Evidence for ellipsis}

Having introduced the data in a nutshell in the previous section, the present section turns to arguments for the elliptical status of relative sluicing. What will be argued for is that the data introduced in the previous section are derived by the elliptical process of sluicing: the TP constituent of the relative undergoes ellipsis and the relative pronoun is left behind as the sole remnant of this process. Taking the landing site of relative pronouns in Hungarian to be Sp,CP (following Kenesei 1992, Kántor 2008), the representation of relative sluicing will be argued to be as in (14). ${ }^{3}$

$$
\begin{aligned}
& \text { A rovaroknak mindig } 3 \text { pár lábuk van, ... } \\
& \text { the insects-DAT always } 3 \text { pair foot-POSs-3PL is } \\
& \text {... a százlábúaknak meg annyi [CPrel amennyi [TP van nekikt]]. } \\
& \text { the millipedes-DAT PRT that.many REL-how.many is they-DAT }
\end{aligned}
$$

And this contrasts crucially with a representation that makes no reference to ellipsis, such as one in which the relative pronoun, or the relative head+relative pronoun sequence constitute a single non-clausal constituent, as in (15):

$$
\begin{array}{llll}
\text {... a százlábúaknak } & \text { meg } \\
\text { the millipedes-DAT } & \text { PRT } & \text { thumP annyi } & \text { amennyi ]. } \\
& \text { that.many } & \text { REL-how.many }
\end{array}
$$

Annyi amennyi 'that.many REL.how.many' in this account would form a complex demonstrative expression of sorts. The rest of this section lists four arguments to the effect that (15) cannot be on the right track and that (14) is a more plausible representation of relative sluicing data.

\subsection{Syntactic distribution}

The first disadvantage of the representation in (15) is that the demonstrative - relative pronoun complex is unattested in any other syntactic environment in the language. To wit, the syntactic distribution of annyi amennyi is clearly different from that of its demonstrative head, the demonstrative annyi: while the latter can, the former cannot be a prenominal modifier for example.

$$
\begin{aligned}
& \text { a. annyi láb } \\
& \text { that.many foot } \\
& \text { 'that many feet' }
\end{aligned}
$$

$$
\begin{array}{ll}
\text { b. * annyi amennyi láb } \\
\text { that.many REL-how.many foot } \\
\text { 'that many feet' }
\end{array}
$$

This difference does not follow from (15) but is straightforwardly predicted by (14). If amennyi is followed by a non-pronounced relative clause, the ungrammaticality of (16b) simply follows from the fact that finite relatives are ungrammatical in prenominal position in Hungarian.

\footnotetext{
${ }^{3}$ In line with previous works of mine, here I follow the so-called PF-deletion approach for the respresentation of the ellipsis site (originating from Ross 1967). In this model, the TP is syntactically built but not pronounced. Other structural approaches posit a single null element (a pro-TP) in the syntax (Hardt 1993, Lobeck 1995). The choice between the two approaches is immaterial for the purposes of this paper.
} 

(17)
annyi [CPrel amennyi van nekik ] láb that.many REL-how.many is they-DAT foot intended: 'the number of feet they have'

This shows that an analysis like (15) therefore is clearly not available for annyi amennyi and its ilk and should only be used for demonstrative - relative pronoun combinations that form a single lexical element. To my knowledge, there is one such case, the idiomatic úgy-ahogy soREL.how 'so-so': this lexeme has a non-compositional meaning and distributes like an adverb the category corresponding to its head, úgy:
A bolt
még úgy-ahogy
tartja
magát.
the shop
still so-REL-how
holds itself
'The shop is so-so alive.'

Apart from the idiomatic úgy-ahogy, however, (15) makes false predictions for the syntactic distribution of productively formed relative sluicing with other demonstrative - relative pronoun combinations, such as the examples (4)-(10) above. And the productive pattern of relative sluicing extends to the entire range of relative pronouns available in the language. A search for 11 frequently occurring relative pronouns in sentence final position in the HNC yielded 312 examples of relative sluicing, see Table 1 for the figures broken down per relative pronoun and per relative clause type. This table reveals that relative sluicing is not confined to only a couple of lexical elements with possibly idiomatic meanings.

Table 1: Number of examples of relative sluicing in the Hungarian National Corpus

\begin{tabular}{|c|c|c|c|}
\hline \multicolumn{2}{|l|}{ relative pronoun } & \multirow{2}{*}{$\begin{array}{c}\begin{array}{c}\text { pronominally } \\
\text { headed RC }\end{array} \\
21\end{array}$} & \multirow{2}{*}{$\begin{array}{c}\text { headless RC } \\
22\end{array}$} \\
\hline$a k i_{\mathrm{sg} / \mathrm{pl}}$ & who & & \\
\hline$a m i_{s g / \mathrm{pl}}$ & what & 53 & 11 \\
\hline amennyi & how much & 10 & - \\
\hline amilyen $_{\mathrm{sg} / \mathrm{pl}}$ & what kind & 43 & 2 \\
\hline amekkora $_{\mathrm{sg} / \mathrm{pl}}$ & what size & 3 & 2 \\
\hline $\operatorname{ahogy}(a n)$ & how & 47 & 10 \\
\hline ahol (-hova -honnan) & where (to, from) & 39 & 4 \\
\hline amerre & which direction & 1 & - \\
\hline ameddig, amíg & till when & 11 & 5 \\
\hline amikor & when & 9 & 9 \\
\hline amennyire & to what extent & 3 & 7 \\
\hline & & 240 & 72 \\
\hline
\end{tabular}

\subsection{Non-adjacency}

A second argument for the representation in (14) and against (15) is that the relative head, when present, can be discontinuous from the relative pronoun and found at a distance from it. In many cases the demonstrative head is found in the preverbal focus position, while the relative pronoun is postverbal. 
(19)

Nem tudom elfogadni azt az érvet, miszerint not know-1SG accept-INF that-ACC the argument-ACC according.to.which majd jövöre csak AzoK kapnak, akik. then next.year only those get-3PL REL-who-PL 'I can't accept the argument that next year only those can receive it who will.'

\begin{tabular}{|c|c|c|c|c|}
\hline hiszen & $\begin{array}{l}\text { a felajánlók } \\
\text { the donators }\end{array}$ & $\begin{array}{l}\text { tudják, } \\
\text { know-3PL }\end{array}$ & $\begin{array}{l}\text { hogy adójuk } \\
\text { that tax-POSS-3PL }\end{array}$ & $\begin{array}{l}\text { meghatározott } \\
\text { fixed }\end{array}$ \\
\hline & $\begin{array}{l}\text { miért } \\
\text { why }\end{array}$ & $\begin{array}{l}\text { éppen } \\
\text { just }\end{array}$ & $\begin{array}{ll}\text { ANNAK } & \text { adják, } \\
\text { that-DAT } & \text { give-3PL }\end{array}$ & REL-who-DAT \\
\hline
\end{tabular}

'... since the donators know why they give a fixed part of their tax to those who they do'

The same would carry over to cases like (21), which involves coordinated relative heads at a distance from the relative pronouns.

$\begin{array}{ll}\text {... és azt } & \text { mímelte, [...] hogy nem is OTT ÉS AKKOR él, } \\ \text { and that.ACC } & \text { pretended that not PRT there and then lives } \\ \text { ahol és } & \text { amikor }\end{array}$

where and $\mathrm{REL}$-when

'... he was pretending $[\ldots]$ that he was not living in the place and at the time when he was'

In a single-constituent analysis like (15), these data would need to be derived by moving a part of the complex constituent out of the complex, a non-default option when dealing with an idiomatic combination of two elements. ${ }^{4}$

\subsection{Distributive readings}

The third argument for an elliptical approach to relative sluicing comes from the strongly distributive subject quantifier $k i-k i$ ' $e a c h$ ' in Hungarian. This quantifier can only be felicitously used if it binds a distributive share (in the sense of Beghelli and Stowell 1997). In the following (a) example there is nothing for $k i$ - $k i$ to distribute over: there is no share. In the (b) example, the bound pronominal in the possessive provides the necessary distributive share for $k i$-ki (indicated by coindexing).
a. $*$ Ki-ki intelligens volt. each intelligent was
'Each of them were intelligent.'
b. $\mathrm{Ki}-\mathrm{ki}_{\mathrm{i}}$ intelligensebb volt a pro $_{\mathrm{i}}$ bátyjánál. each intelligent-COMP was the brother-POSS-3SG-AT 'Each of them were more intelligent than their brothers.'

\footnotetext{
${ }^{4}$ Note also that infrequently, relative sluicing can also be found with lexical nouns in the head of the relative.

(i) ... Ausztriában, ahol most az a kormány van, amelyik.

Austria-IN REL-where now that the government is REL-which

'... in Austria, where the kind of government is (in power) which is (in power)'

This indicates that in a structure like (15), the single constituent hypothesized should contain a slot for a free lexical restriction; something that is evidently not expected if the single constituent is idiomatic in nature.
} 
Consider now (23), in which a distributive relation is difficult to construe as the object refers to a definite specific entity. The result is very poor:
?* $\mathrm{Ki}^{-k i_{i}} \quad$ megcsókolta az
azt (az embert).
each kissed-3SG that-ACC
the man-ACC
'Each of them kissed that man.'

No such problem arises, however, if the object is modified by a relative clause that contains a bound pronominal subject, like in the following two examples. In these, $k i-k i$ has a suitable distributive share:
a. Ki-ki $i_{i}$ megcsókolta azt,
akit
pro $_{i}$ látott.
each kissed-3SG that-ACC REL-who-ACC
saw-3SG
'Each of them kissed whoever they saw.'
b. Ki-ki $i_{i}$ megcsókolta azt, akit each kissed-3SG that-ACC REL-who-ACC
proi megcsókolt.
'Each of them kissed whoever they kissed.'

Crucially, relative sluicing patterns with the latter examples by being grammatical with $k i-k i$ in the main clause. Thus, (25) expresses the same meaning as (24b) and is perfectly well-formed:
Ki-ki $\mathrm{i}_{\mathrm{i}} \quad$ megcsókolta azt, akit.
each kissed-3SG that-ACC REL-who-ACC
'Each of them kissed whoever they did.'

If (25) is an elliptical instance of (24b), and thus derives from an underlying structure similar to that of (24b), the possibility of distibutive binding and the grammaticality of the example follows without any further ado. Under an account in which azt akit forms a single constituent, the wellformedness of (25) is not predicted: indeed, this account would rather predict that (25) should be as degraded as (23) due to the lack of a distributive share.

\subsection{Traits of antecedent contained deletion}

The last argument for relative sluicing involving ellipsis comes from a set of observations that show that relative sluicing shows traits of antecedent contained deletion, most specifically traits of antecedent contained sluicing, and as such a part of it must be affected by an elliptical process.

Antecedent contained deletion is the cover term for ellipsis phenomena in which an elided phrase is contained in a phrase whose meaning it depends on for purposes of ellipsis resolution (Bouton 1970, May 1985, Hornstein 1995, Kennedy 1997, Merchant 2000, Hackl et al 2012). This is typically a case where VP ellipsis takes place inside a relative clause, cf. (26): ${ }^{5}$

\footnotetext{
${ }^{5}$ The standard syntactic solution to ensure that the resolution of the missing VP material does not incur infinite regress is to assume that quantifier raising applies to the relative clause, to adjoin to a matrix constituent that is minimally as high as the elided constituent itself: this means minimally to the matrix VP. See Merchant (2000) for an argument in terms of NPI licensing that VP-adjunction for ACD containing VP ellipsis should be allowed.
} 
(26) a. Dulles [vp suspected everyone [CPrel Angleton did [vp - ]]].

b. That boy [vp won't do a damn thing [CPrel I ask him to [vp - ]]].

If Hungarian relative sluicing is an instance of ellipsis, it corresponds very closely to a configuration like (26), except that the elided category is a TP and not a VP (i.e. Hungarian elides a clausal category, while English only a predicate). The missing TP in turn is contained in the matrix TP constituent — representing a case of antecedent contained sluicing (ACS):

$$
\begin{aligned}
& \text { Ki-ki [TP megcsókolta azt [CPrel akit [TP - ]]] } \\
& \text { each kissed that-ACC REL-who-ACC }
\end{aligned}
$$

Interestingly, antecedent contained sluicing, that is, instances of TP ellipsis with antecedent containment, have been found to exist in English as well. The relevant facts of English exhibit sluiced $w h$-interrogatives inside PPs like the following (Yoshida 2010, Tanaka 2011, Yoshida \& Gallego 2012):

(27) a. Everyone got sick [PP without knowing why [тр — ]].

b. John must love someone [рP without knowing who [тр - ]].

c. John does not love anyone [PP without knowing who [тр - ]].

Such cases of ACS furthermore have a unique characteristic profile when it comes to ellipsis identity: quantificational subjects, modals and negation are (in certain contexts) not recovered in the ellipsis site. That is, while these are part of the antecedent TP in English, they are not part of the missing TP (provided in brackets):

(28) a. Everyone got sick without knowing why (he got sick / *everyone got sick).

b. John must love someone without knowing who (he loves / *he must love).

c. John does not love anyone without knowing who (he loves $/ *$ he does not love).

Hungarian relative sluicing fully parallels English antecedent contained sluicing in the above properties as well. First, a universal quantifier in the matrix clause is interpreted as a bound variable in the ellipsis site:
Mindenki megcsókolta azt,
akit $\left(\mathrm{pro}_{\mathrm{i}} / *\right.$ mindenki) megcsókolt. everyone kissed.3SG that-ACC REL-who-PL pro everyone kissed-3sG 'Everyone kissed whoever he kissed.'

Second, negation and conditional mood is not construed as part of the ellipsis site, either:

(30) Pénzügyi válság nélkül nem tartottunk volna ott, finencial crisis without not be-PAST-3PL COND there ahol (tartottunk $/ *$ nem tartottunk volna). REL-where be-PAST-3PL not be-PAST-3PL COND 'Without the financial crisis we would not have been wherever we were.' 
Putting aside the question why this unique profile of interpretation obtains in these examples (see Yoshida 2010, Yoshida \& Gallego 2012, Thoms 2013 for explanations for the English facts), what is important is that both English ACS and Hungarian relative sluicing feature the same kind of breakdown of strict identity in exactly the same environments. And this in turn presents an argument for treating Hungarian relative sluicing as an instance of antecedent contained deletion of a TP constituent.

This concludes the argumentation about ellipsis being part of the derivation of relative sluicing examples. The present section has provided converging evidence from four aspects of syntactic behavior for the claim that relative sluicing contains deletion.

\section{The licensing of relative sluicing}

This final section gives an account of the licensing of relative sluicing and in this way returns to the topic of the introduction. While we have successfully shown that sluicing inside relative clauses is possible contrary to received opinion, the puzzle concerning the distinction between interrogatives and relative clauses can be reformulated such that it concerns language variation: Why does Hungarian allow for sluicing inside relatives while languages like English do not? The answer to this question has two components: as will be argued on the next pages, relative sluicing is possible in Hungarian due to the interplay of syntactic and prosodic licensing.

\subsection{Syntactic licensing}

The syntactic licensing of relative sluicing in Hungarian is due to the same licensing mechanism that is operative in sluicing in other non-interrogative domains as well, such as indicative clauses. The crucial observation relevant here is that in languages in which wh-movement in constituent questions is indistinguishable from movement of other constituents allow sluicing after such constituents as well — cf. van Craenenbroeck \& Lipták (2006, 2013) for Hungarian, as well as Grebenyova (2006) for Russian, Hoyt \& Theodorescu (2012) for Romanian, Lipták \& Aboh (2013) for Gungbe.

For Hungarian specifically, van Craenenbroeck and Lipták (2006) have shown that sluicing can leave any operator phrase in the left periphery, not only wh- or focus-constituents but also (universal) quantifiers.

(31) János meghívott egy lányt, de nem tudtam, hogy $\{$ kit / ANNÁT . János invited a girl-ACC but not knew-1SG COMP who-ACC Anna-ACC 'János invited a girl, but I didn't know \{who / that it was Anna $\}.$ '

Tudtam, hogy János sok lányt $\begin{aligned} & \text { meghívott, } \\ & \text { knew-1SG that János many girl-ACC }\end{aligned}$ PV-invited-3SG but not knew-1SG
hogy mindet.
COMP all-ACC
'János invited many girls, but I don't know he invited every one of them.'

To capture this broad range of sluiced remnants the above authors suggested that ellipsis licensing in Hungarian sluicing should in fact make reference to an operator feature on the 
remnant and on the functional head whose complement elides. ${ }^{6}$ Accordingly, in Hungarian the [E] feature should be defined to have an operator feature, $\mathrm{E}_{[u \mathrm{Op}}$, , which requires checking in overt syntax against an operator that moves above the TP. The net effect is that while English sluicing deletes the complement of (the highest) $\mathrm{C}^{\circ}$, Hungarian sluicing deletes the complement of an operator head, such as $\operatorname{Foc}^{0}$.
a. English sluicing
b. Hungarian sluicing
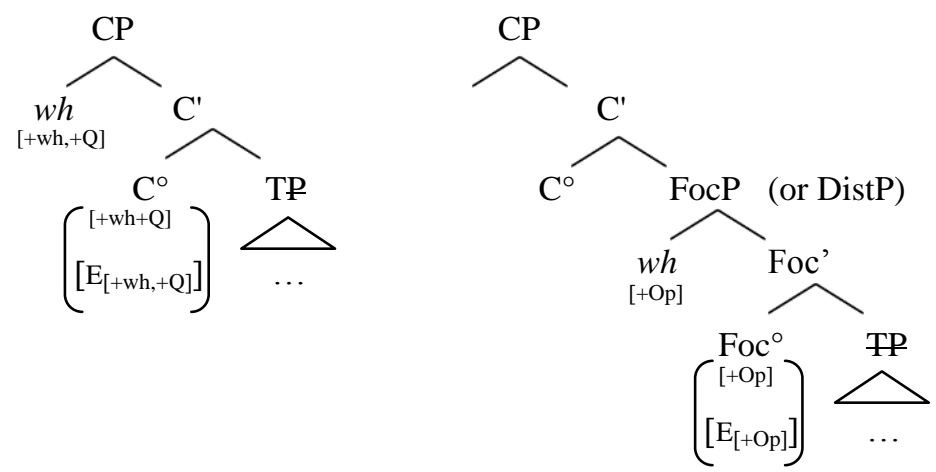

Given that relative clauses involve movement of an operator constituent into a left peripheral CP position (see Kenesei 1992 and Kántor 2008 for arguments to this effect), the licensing of relative sluicing should proceed along the same lines as in (33b). The relative operator, similarly to the [E] feature, checks an operator feature on $\mathrm{C}^{0}$ and sluicing deletes the complement of $\mathrm{Op}^{0}$ :

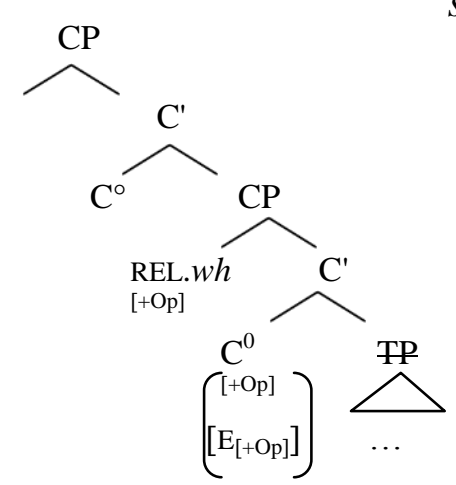

syntactic licensing of relative sluicing in Hungarian

The account of ellipsis licensing presented here makes the prediction that languages in which whmovement and relative operator movement are sufficiently alike should show evidence for relative sluicing as well. One language for which this prediction is fulfilled is the Niger-Congo language Gungbe (Lipták and Aboh 2013). In Gungbe, wh- and focus elements move to the same

\footnotetext{
${ }^{6}$ In more exact detail the authors suggest that sluicing tracks $w h$-syntax in languages: the feature content of $w h$ elements in non-elliptical questions determines what kind of remnants can escape TP-ellipsis in sluicing. In an [E]feature approach like Merchant's (2001), this boils down to the licensing requirement making reference to features on the remnant relativized to the type of features found on interrogatives, as stated in (i)

(i) THE WH/SLUICING-CORRELATION (van Craenenbroeck and Lipták 2006)

The syntactic features that the [E]-feature checks in a certain language are identical to the strong features a whphrase checks in a non-elliptical constituent question in that language.
} 
position, and free relatives also front relative expressions in the fashion of focus movement. In the latter contexts, sluicing is possible (Lipták and Aboh 2013, ex. 8): ${ }^{7}$

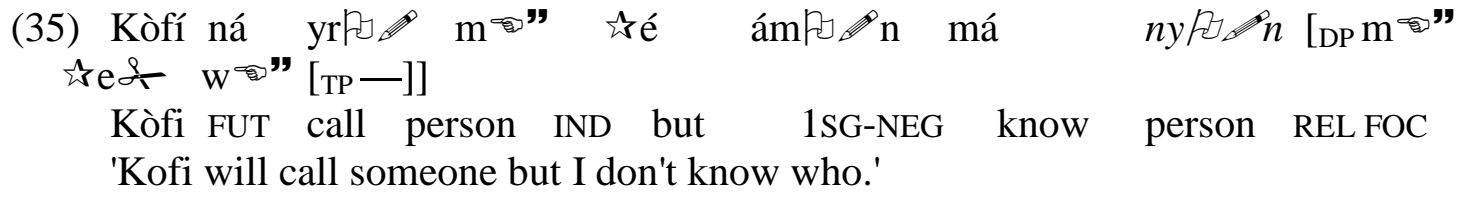

A quick glance at a handful of other languages (Romanian, Russian, Bulgarian, Polish, Croatian, Czech, Slovenian, Serbian, Greek, Albanian, Portuguese, Italian, French, Spanish, Hindi and Bangla) reveals, however, that relative sluicing is typologically rare: none of these languages allow for the kind of relative sluicing that occurs in Hungarian. This holds interestingly also for Romanian, a language in which sluicing after focal items and quantificational expressions is allowed similarly to Hungarian (Hoyt and Teodorescu 2012), but relative sluicing is impossible (Dafina Raţiu p.c.). The unavailability of relative sluicing in Romanian suggests that next to syntactic licensing, yet another licensing requirement is operative in relative sluicing in Hungarian, which operates hand in hand with syntactic licensing.

\subsection{Prosodic licensing}

The second licensing requirement effective in relative sluicing has to do with the pronunciation of the elliptical sentence. As has been noted from time to time in the literature, the remnants escaping clausal ellipsis must be able to bear stress. Following Sáez (2011) this can be formulated as follows (see also Sprouse 2006):

\section{(36)}

\section{Stress Condition on Remnants}

Every ellipsis remnant must bear stress.

In the case of clausal ellipsis, the stress requirement is arguable a requirement for the remnant to carry nuclear sentence-level prominence. For wh-, focus and quantifier remnants in sluicing, such as those in (31/32), the stress condition can be easily satisfied in ellipsis: question words, focus constituents and quantifiers are capable of bearing focal accent (Surányi et al 2012). The same holds for relative pronouns that are contrastive, as in example (9) above.

Non-contrastive relative pronouns on the other hand cannot normally be associated with focal accent. In non-elliptical contexts, relative pronouns being functional elements, are stressless (Selkirk 2004), the claim that has been made in the literature on Hungarian specifically, too, as in Kálmán \& Nádasdy (1994), who consider relative pronouns unstressed $\left(^{0}\right.$ ) (see also Varga 2002 in whose terminology they are minor-stressed). The stressless nature of relative pronouns can

\footnotetext{
${ }^{7}$ Another languages in which relative sluicing has been documented is Brazilian Portuguese, see (i) from Rodrigues et al (2009, ex. 58) (although according to our informants, the grammatical status of this example is questionable; Sergio Menuzzi, Amanda Post Da Silveira p.c.). As the authors argue, the movement of quem in this free relative is for all intents and purposes identical to the derivation of $w h$-questions.

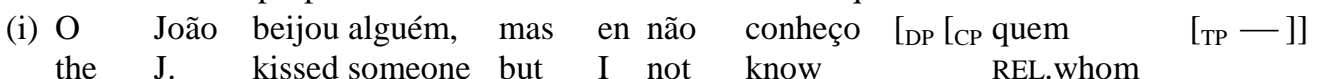

'João kissed someone but I don't know who.'

Note that both Brazilian Portuguese and Gungbe use free relatives in lieu of embedded questions, as the selecting predicates, nys' $n$ 'know' in (45) and conhecer 'know' in (i) can only have DP complements and not propositional ones.
} 
also be observed in relative clauses of the sort that can give rise to relative sluicing: if there is no ellipsis in them, the relative pronoun is unstressed, while the predicate that follows it bears phrasal prominence characteristic of major constituents in the language (indicated by $\left.{ }^{\mathbf{}}\right){ }^{8}$

\begin{tabular}{|c|c|c|c|}
\hline $\begin{array}{l}\text { Mindenki } \\
\text { everyone }\end{array}$ & $\begin{array}{l}\text { `megcsókolta } \\
\text { kissed-3SG }\end{array}$ & $\begin{array}{l}\text { vazt, } \\
\text { that-ACC }\end{array}$ & $\begin{array}{l}{ }^{0} \text { akit } \\
\text { REL-who-ACC }\end{array}$ \\
\hline
\end{tabular}

'Everyone kissed whoever he/she kissed.'

When relative sluicing takes place, however, and the TP is unpronounced and thus incapable of bearing any stress, the relative pronoun becomes stressed instead. In this way, it complies with (36):

$\begin{array}{llll}\begin{array}{l}\text { 'Mindenki } \text { 'megcsókolta } \\ \text { everyone }\end{array} \text { kissed-3SG } & \text { 'akit. } \\ \text { that-ACC } & \text { REL-who.ACC } \\ \text { Everyone kissed whoever he/she kissed.' } & \end{array}$

Independent support that this stress pattern is possible in Hungarian comes from relative clauses in which the relative pronoun is the only overt element in the relative clause, as it is followed only by phonetically zero items. Such examples are not difficult to come by as Hungarian has phonetically null subjects (pro-drop) and a zero copula in 3 rd person present tense contexts. In case where a 3rd person present tense copula is combined with a nominal or adjectival predicate represented by the relative pronoun, everything but the relative pronoun must be null — these examples then can have a non-elliptical parse illustrated in (40/41): ${ }^{9}$

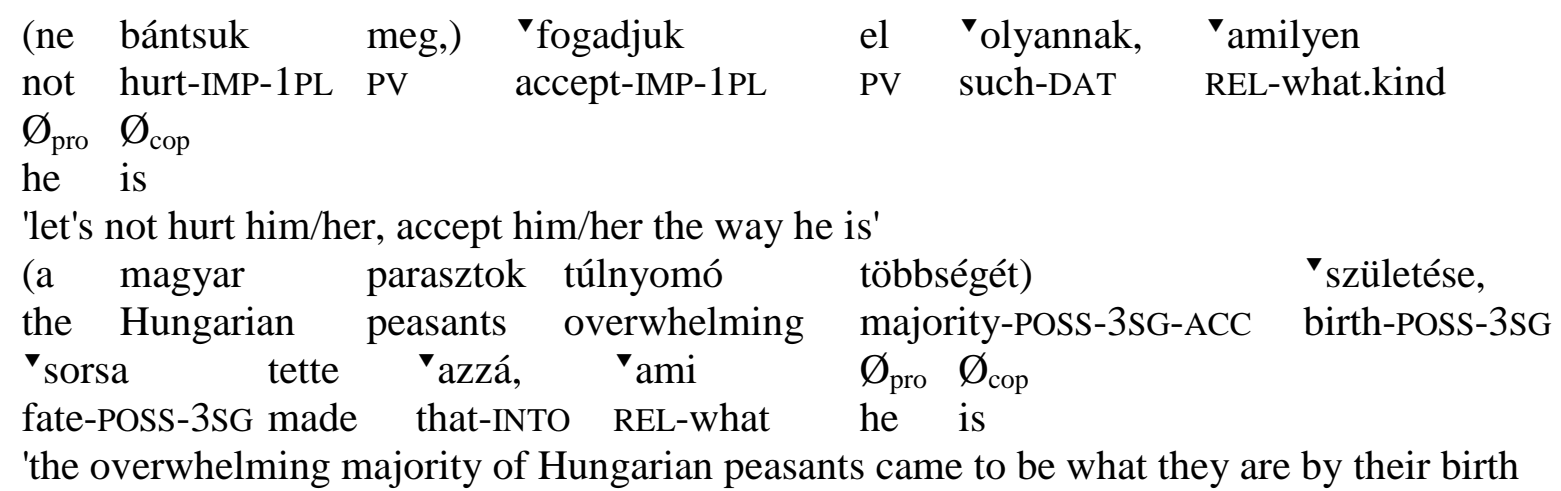

${ }^{8}$ There are two exceptions to the claim that relative pronouns are unstressed: contrastive relative pronouns cf. the example (9) above, and free choice free relatives pronouns marked with focus particle csak 'only':
(i) "Elvehetsz, "amit $\quad{ }^{0}$ csak "akarsz.
take-POT-2SG REL-what-ACC only want-2SG
'You can take whatever you want.'

${ }^{9}$ Should the copula be in the past or any other person than 3rd, it can no longer be overt, as the following examples show. Note that as long as the copula is overt, it comes out with phrasal prominence, leaving the relative pronoun stressless, just like in the case of (38) above.
(i) a. "Elfogadtuk $\nabla^{\prime}$ olyannak, ${ }^{0}$ amilyen $\quad \emptyset_{\text {pro }} \quad \nabla_{\text {volt. }}$ accepted-1PL such-DAT REL-what.kind he be-PST-3SG 'We accepted him/her the way he/she was.'
a. 'Elfogadunk 'olyannak, ${ }^{0}$ amilyen $\varnothing_{\text {pro }} \quad{ }^{\prime}$ vagy. accept-1PL such-DAT REL-what.kind he be-2SG
'We accept you the way you are.'




\section{and their fate'}

As the accent marks show, examples of this sort involving a phonologically null TP are pronounced in the same way as relative sluicing. In both cases there is obligatory stress on the sentence-final relative pronouns. ${ }^{10}$

An examination of the frequency of data like (40) and (41) in the Hungarian National Corpus furthermore reveals that these kind of examples more frequently give rise to string-final relative pronouns than the examples in which the missing TP can only be due to ellipsis. ${ }^{11}$

${ }^{10}$ Next to the obligatory stress on the relative pronoun, further ingredients of prosodic realization show parallels in the two types of examples, too. One is that the relative pronoun in these constructions has to correspond to a single prosodic word, and cannot be complex, by way of containing a which-type relative pronoun followed by a noun or other material pied-piped with the relative pronoun. This restriction seems entirely prosodic in nature as there are no syntactic or semantic reasons why these complex pronominals should be ill-formed:

(i) Az építményadót eddig ugyanis a kerületek szedték — már amelyik (* kerület). the property.tax-ACC $t$ ill.now PRT the districts collected PRT REL-which district lit. 'It was the districts that collected the property tax — at least whichever districts did.'

(ii) Mindenki megcsókolta azt a lányt, $\quad$ amelyiket $\quad / *$ amelyik lányt $\}$. everyone kissed-3SG that-ACC the girl-ACC REL-who-ACC REL-which girl.ACC

'Everyone kissed the girl he/she kissed.'

(iii) János olyan apa, amilyen (*apa).

János such father REL-what.kind father

'János is the kind of father he is.'

A further consequence of the single word requirement of the relative pronoun is that relative pronouns in relative sluicing cannot be followed by postpositions either. Consider the following minimal pair:

(iv) a. Mindenki jól érezte magát azzal, akivel.

everyone well felt himself that-WITH REL-who-WITH

'Everyone had a good time with the person he/she had a good time with.'

b. * Mindenki jól érezte magát a nélkül, aki nélkül.

everyone well felt himself that without REL-who WITHOUT

' Everyone had a good time without the person he/she had a good time without.'

I leave the specifics of these prosodic restrictions for future investigation, with just noting that they are somewhat reminiscent of the restrictions on swiping in English (inversion of a wh-operator around a preposition under sluicing, Merchant 2002). In swiping, just like in relative sluicing, the sluiced $w h$-phrase has to be 'minimal', in the sense of not being a phrase, but a monomorphemic item (thanks to an anonymous reviewer for noting this):

(v) Lois was talking, but I don't know $\left\{\right.$ who $/{ }^{*}$ which girl $\}$ to. swiping, English

See also Southern Dutch spading (a sluicing-specific process whereby a $w h$-phrase is followed by a demonstrative) for a similar restriction, too (van Craenenbroeck 2010).

${ }^{11}$ When classifying the corpus data, the preceding context of the utterance was taken to be the decisive factor. All examples for which a present tense interpretation of the relative clause was possible were classified as containing a phonologically zero TP in the right column. Note that the claim is not that these examples cannot be elliptical, but rather that they have a perfectly well-formed non-elliptical parse as well, next to a possible elliptical one. 
Table 2: The number of string-final relative pronouns the HNC (approximate)

\begin{tabular}{|l|l|l|}
\hline & elliptical TP & $\begin{array}{c}\text { phonologically zero TP } \\
\text { (due to } \boldsymbol{\emptyset}_{\text {pro }} \boldsymbol{\emptyset}_{\text {cop }} \text { ) }\end{array}$ \\
\hline${\text { aki } i_{\mathrm{sg} / \mathrm{pl}}}$ & 43 & 53 \\
\hline ami $_{\text {sg/pl }}$ & 64 & 181 \\
\hline amennyi $^{\text {amilyen }} \mathrm{sg} / \mathrm{pl}$ & 10 & 21 \\
\hline amekkor $_{\mathrm{sg} / \mathrm{pl}}$ & 45 & 312 \\
\hline ahogy an $)$ & 5 & 10 \\
\hline ahol $(-$ hova - honnan $)$ & 57 & - \\
\hline amerre & 43 & - \\
\hline ameddig & 1 & - \\
\hline amikor & 6 & - \\
\hline amig & 18 & - \\
\hline amennyire & 10 & - \\
\hline total: 889 & 10 & - \\
\hline percentage in total & $\mathbf{3 1 2}$ & $\mathbf{5 7 7}$ \\
\hline
\end{tabular}

This demonstrates that the stress pattern required in relative sluicing according to (36) is independently available in the language, and this provides a necessary (but not sufficient) condition for the satisfaction of (36) in the context of relative sluicing, too.

And now we are in position to make an educated guess about role of (36) in ruling out relative sluicing in other languages: possibly, the reason why Romanian does not show evidence for relative sluicing is due to its inability to place stress on a relative pronoun. In other words, while the syntactic licensing condition is satisfied, the prosodic one is not. In Romanian, there is no evidence for string-final relative pronouns as this language, unlike Hungarian, does not have zero copulas, thus configurations like (40/41) can never arise.

If this is the right way of thinking about the cross-linguistic availability of sluicing, we find an explanation for why relative sluicing is quite restricted among languages: next to a syntactic licensing (section 4.1), prosodic licensing defined as in (36) is also part of the licensing restriction on relative sluicing. ${ }^{12}$

\section{Summary}

The present case study on Hungarian argued for the existence of TP ellipsis inside relative clauses to the exclusion of relative pronoun. It was shown that restrictive relative clauses with a free choice interpretation can involve clausal ellipsis. The arguments were based on various aspects of syntactic behavior, such as syntactic distribution, binding and traits of antecedent contained deletion. It was concluded that relative sluicing is expected to be possible in languages in which relative pronouns and interrogative wh-constituents are targeted by the same kind of movement and in which relative pronouns are capable of bearing sentence-level main prominence.

\section{Acknowledgements}

I thank Jeroen van Craenenbroeck for discussions back in 2005, which made me realize the existence of relative sluicing for the first time. More recently, I am indepted to two anonymous

\footnotetext{
${ }^{12}$ Note that the prediction of this account cannot be checked for Gungbe (see 35 above), as Gungbe is a tone language. At this point I do not know about any other language that, like Hungarian, licenses relative sluicing and shows the described effects of prosodic licensing.
} 
reviewers, as well as Enoch Aboh, James Griffiths, and the audience of the ICSH 11 conference at Pázmány University, Hungary, for useful comments. This work is supported by the Netherlands Organization of Scientific Research (NWO).

\section{References}

Beghelli, Filippo \& Tim Stowell 1997. Distributivity and negation. In Anna Szabolcsi (ed.), Ways of scope taking, 71-107. Dordrecht: Reidel.

Bouton, Lawrence F. 1970. Antecedent-contained proforms. In Mary Ann Campbell et al (eds), Papers from the Sixth Regional Meeting, Chicago Linguistic Society 6, 154-167. University of Chicago: Chicago Linguistic Society.

Citko, Barbara 2004. On Headed, Headless, and Light-Headed Relatives. Natural Language and Linguistic Theory 22. 95-126.

Craenebroeck, Jeroen van. 2010. The syntax of ellipsis. Evidence from Dutch dialects. Oxford / New York: Oxford University Press.

Craenenbroeck, Jeroen van and Anikó Lipták. 2006. The cross-linguistic syntax of sluicing: evidence from Hungarian relatives. Syntax 9. 248-274.

Dayal, Veneeta. 1997. Free choice and ever: Identity and free choice readings. In Aaron Lawson (ed), Proceedings of SALT 7, 99-116. Ithaca, NY: CLC Publications, Cornell University.

von Fintel, Kai. 2000. Whatever. In Brendan Jackson and Tanya Matthews (eds), Proceedings of SALT 10, 27-40. Ithaca, NY: CLC Publications, Cornell University.

Hackl, Martin. et al. 2012. Quantification and ACD. Journal of Semantics 29. 145-206.

Hoyt, Frederik and Alexandra Teodorescu. 2012. How many kinds of sluicing, and why? Single and multiple sluicing in Romanian, English and Japanese. In K. Johnson \& J. Merchant (eds), Sluicing: $a$ cross-linguistic perspective, 83-103. Oxford: Oxford University Press.

Jacobson, Pauline. 1995. On the quantificational force of English free relatives. In. Emond Bach, Eloise Jelinek, Angelika Kratzer, and Barbara Partee (eds), Quantification in natural language. 451-486. Dordrecht: Kluwer.

Kálmán, László and Ádám Nádasdy. 1994. A hangsúly. In Ferenc Kiefer (ed), Stukturális Magyar Nyelvtan II. Fonológia, 393-467. Budapest: Akadémiai Kiadó.

Kántor, G. 2008. On Hungarian Relative Operators. In László Varga (ed.), The Even Yearbook 8. ELTE SEAS Working Papers in Linguistics ELTE Budapest. Available online at: http://seas3.elte.hu/delg/publications/even/2008.html (accessed on 14.7.2014).

Kenesei, István. 1992. Az alárendelt mondatok szerkezete. In Ferenc Kiefer (ed.) Strukturális magyar nyelvtan 1. Mondattan, 529-713. Budapest: Akadémiai Kiadó.

Kennedy, Chris. 1997. Antecedent-contained deletion and the syntax of quantification.Linguistic Inquiry 28. 662-688.

Lipták, Anikó \& Enoch Aboh. 2013. Sluicing inside relatives: the case of Gungbe. In Suzanne Aalberse and Anita Auer (eds), Linguistics in the Netherlands 2013, 102-118. Amsterdam/Philadelphia: John Benjamins.

Merchant, Jason. 2000. ACD in negative polarity items. Syntax 3. 144-150.

Merchant, Jason. 2001. The syntax of silence. Oxford / New York: Oxford University Press.

Merchant, Jason. 2002. Swiping in Germanic. In C. Jan-Wouter Zwart and Werner Abraham (eds), Studies in comparative Germanic syntax, 295-321. Amsterdam/Philadelphia: John Benjamins.

van Riemsijk, Henk. 1978. A case study in syntactic markedness: the binding nature of prepositional phrases. Dordrecht: Foris.

Rodrigues, Cilene, Andrew Nevins and Luis Vicente. 2009. Cleaving the Interactions between Sluicing and Preposition Stranding. In Leo Wetzels and Jeroen van der Weijer (eds), Romance Languages and Linguistic Theory 2006, 175-198 Amsterdam/Philadephia: John Benjamins. 
Sáez, Luis. 2011. Peninsular Spanish prenominal possessives in ellipsis contexts: A phase-based account. In Julia Herschensohn (ed.), Romance Linguistics 2010: selected papers from the 40th Linguistic Symposium on Romance Languages (LSRL), 155-176. Amsterdam/Philadephia: John Benjamins.

Selkirk, Elisabeth. 2004. The prosodic structure of function words. In John J. McCarthy (ed.) Optimality theory in phonology. A reader, 464-482. Malden / Oxford: Wiley-Blackwell.

Sprouse, Jon. 2006. The Accent Projection Principle: Why the hell not? In Aviad Eilam, Tatjana Scheffler and Joshua Tauberer (eds), Proceedings of the 29th Penn Linguistics Colloquium, Penn Working Papers in Linguistics 12.1. 349-359. Pennsynvania: Penn Graduate Linguistics Society.

Surányi, Balázs, Shinichiro Ishihara \& Fabian Shubö. 2012. Syntax-prosody mapping, topic-comment structure and stress-focus correspondence in Hungarian. In Gorka Elordieta and Pila Prieto (eds), Prosody and meaning, 35-71. Göttingen: Mouton de Gruyter.

Tanaka, Hidekazu. 2011. Remarks on Antecedent Contained Sluicing. Ms. York University.

Thoms, Gary. 2013. Lexical mismatches and the identity condition. In Stefan Keine and Shayne Sloggett (eds), NELS 42 Proceedings, 559-572. Amherst: GSLA.

Yoshida, Masaya \& Ángel J. Gallego. 2012. Phases and Ellipsis. In Artemis Alexiadou, Tibor Kiss and Gereon Müller (eds.), Local Modeling of Non-Local Dependencies in Syntax, 353-370. Tübingen: Niemeyer.

Yoshida, Masaya. 2010. "Antecedent Contained" Sluicing. Linguistic Inquiry 41. 348-356.

Varga, László. 2002. Intonation and Stress: Evidence from Hungarian. Houndmills, Basingstoke: Palgrave-Macmillan. 